\title{
OUTDOORS ON THE SHORES OF THE BALTIC: GRADIENCE IN THE GRAMMATICALIZATION OF THE EXTERIOR- REGION
}

\author{
Andres Karjus \\ University of Tartu
}

\begin{abstract}
The change of a lexical element into a grammatical (closed class) element must necessarily include intermediary stages where the element is considered gradually less lexical and more grammatical. The central assumptions in this study are the gradualness and gradience of grammaticalization, that natural language change cannot happen overnight, and that the change is driven by individual speakers of a language community (cf. Traugott and Trousdale 2010: 23, 26). Using a data sample from a questionnaire on spatial grams of the EXTERIOR-REGION (cf. Svorou 1994) in Estonian, Võro and Latvian, an attempt is made to model diachronic gradualness through synchronic gradience. The analysis and the explication thereof are carried out using multidimensional scaling, a statistical modelling method used akin to semantic maps.
\end{abstract}

Keywords: grammaticalization, gradualness, gradience, spatial grams, multidimensional scaling, Circum-Baltic languages

\section{Introduction}

\subsection{Spatial grams of the EXTERIOR-REGION}

The multidimensional scaling model is used to determine the distributions of eight spatial grams (in the sense used in Svorou 1994) in Estonian, Voro and Latvian, all of which carry the (directional) sense of 'out, to the outdoors'. This paper aims to explore the gradience in the usage of these grams - and how this gradience may provide insights into their grammaticalization paths. The sample of grams is namely motivated by similar paths of grammaticalization, having developed the gram 'out' 
from nouns denoting 'field' and '(court)yard', lexemes referring to something that is outside of one's door, in the EXTERIOR-REGION - with the exception of Vorro, which has an additional spatial gram for 'out' with the lexical source of the 'door' itself. The study concentrates on the usage and distribution of those grammaticalized grams, not the domain of expressions for movement to the EXTERIOR-REGION in general (for which a variety of other means can be employed, such as case-marking, but also verbal affixes in Baltic languages that often focus on the elative rather than the lative aspect of the movement).

The spatial grams under observation in this study are the following. In Estonian, there is välja 'out' (grammaticalized from a lative case of väli 'field'), väljapoole 'outwards, to the outside' (combined with poole 'towards', a grammaticalized lative form of pool 'side') and oue 'to the outdoors' (grammaticalized from the illative form of $\tilde{o} u$ 'courtyard'). Võro has the cognates vällä 'out', välläspoolõ 'to the outside', but also, to some extent, ussõ 'to the outdoors' (a grammaticalized lative form of uss 'door'). Latvian has $\bar{a} r \bar{a}$ 'out' (grammaticalized locative of $\bar{a} r s$ 'arable land, clearing'), $u z \bar{a} r u$ 'to the outside' (the accusative form of $\bar{a} r s$, combined with a directional preposition) and lauk $\bar{a}$ 'out' (locative of lauks 'field'). Some of these grams can only be used in referring to movement from the indoors of a dwelling to the outdoors, while others (notably the Finnic välja/vällä) have gone through further desemanticization and extension to become more general out-grams, and have been decategorialized, producing semi-productive aspect markers (the latter function is not covered in this study). All of these grams described above have parallel forms for the locative and elative function as well (with the exception of the Latvian lauk $\bar{a}$ that does not have an elative form).

This kind of grammaticalization is not uncommon from the areal perspective. For the 'to the outdoors' sense, Polish has the spatial gram na dwór (grammaticalized from the combination of the preposition $n a$ 'to, at' and dwór 'courtyard') and, in some southern varieties, na pole (with pole 'field'). Russian has na ulicu (the cognate preposition with ulica 'street') and na dvor 
in some varieties (interestingly, in American Russian an analogical construction, na autsajde, from the English outside, has been observed (Andrews 1999:65)). Votic has the grams kujalõo, akkunalaa (derived from 'street' and 'window' respectively), but also the Finnic cognate vällää (cf. VKS), while Karelian has pihale (allative of piha 'yard' (KKVS)). SSAE (334) reports the usage of the Finnish pellolle (allative of pelto 'field') with the meaning of 'out, away', but mostly in the eastern dialects. In the extinct Baltic language of Prussian, the spatial gram used for that function was winna, derived from the noun wins 'air' (Mažiulis 1997:240), much like the Lithuanian $i$ išore 'to the outside' (cf. Karulis 2001). In Lithuanian, cognates of the Latvian lauk $\bar{a}$ gram are also used, although somewhat variably: $i$ lauka (grammaticalized accusative of laukas 'field' with a directional preposition), laukan (illative form) and simply lauk. Similar examples can be found beyond the Circum-Baltic as well: the Sölkup pōnä 'out' comes from po 'tree, forest' (Hell and Katz 1982:175-177) and the Basque kanpora from the Spanish loanword for 'field' (de Rjik 2008:75), while the Võro ussõ happens to be similar to the Latin foris 'out' (also grammaticalized from 'door'; cf. also English outdoors (Svorou 1994: 258)).

\subsection{Theoretical assumptions}

This study makes use of the model of grammaticalization developed by Heine and Kuteva (cf. 2006:43), which consists of the parameters of extension (the use in new contexts suggests new meanings), desemanticization (loss in meaning content), decategorialization (loss in morphosyntactic properties) and erosion (loss in phonetic substance). Before proceeding, it should also be noted (following the example of Heine and Kuteva 2006: 47) that when it is claimed here that a given language has developed a spatial gram or has grammaticalized this or that lexical element, then it goes without saying that languages cannot do such things by themselves - rather, it is the speakers using a language who do. 
Synchronic gradience is understood as variation within a language community that is "the result of small-step changes such as are associated with gradualness", while "some instances of synchronic gradience may be the result of grammaticalization", according to Traugott and Trousdale, who also see gradience as "an ideal testing ground for hypotheses about the expressions that are most likely to undergo grammaticalization, and perhaps more critically, the way in which grammatical constructions emerge" (2010: 26, 39, 40). Gradualness expresses the assumption that most (natural) linguistic change involves smallstep changes, and can also be considered to be in many ways the diachronic dimension of gradience (Traugott and Trousdale 2010: 23).

In the following sections, the questionnaire data on the usage of the aforementioned spatial grams will be presented, after which a cline of grammaticalization, reflected by the gradience in the synchronic sample, will be proposed.

\section{The method and the questionnaire}

\subsection{The questionnaire}

A series of experiments were carried out, using online picture questionnaires. The questionnaire consisted of 10 grey-scale images (developed based on a preceding pilot study with 40 images), depicting different situations of exiting. Every image consisted of two parts, divided by a horizontal line: the initial state, the figure (coloured red against the grey-scale background) being inside an object or within some boundaries, and the movement, where the figure moved or was moved outside of the previous boundaries, augmented with a red arrow indicating the path of the movement. The images were presented in a random order for every test subject. Under each image was a selection of words (three or four depending on the language, plus an "other" option with a comment box) and the subjects were supposed to, according to the instructions given beforehand, rate the words on a scale 
of 0-5 (represented by little yellow stars), based on whether they would use them to describe the scenes above.

The sample consisted of 42 speakers of Estonian, 101 speakers of Latvian and 26 speakers of Võro (South Estonian). Due to the nature of this study, the difference in the number of speakers should not pose a problem for the analysis in the following. Lithuanian data is also being collected, but there are too few subjects as of yet to include them here. The questionnaires were distributed mainly through online social networks and mailing lists, wherefore the selection of subjects may have been somewhat biased.

For the present study, data on four images from the aforementioned questionnaire are used: man exiting house onto street and man exiting house into field, as the most prototypical exiting situations; man exiting an aeroplane in flight (as a non-canonical exiting situation); and finally, an abstract spherical object exiting an abstract rectangle (see Figure 1). The first two images represent the arguably least desemanticized stages of grammaticalization, contrasted with two situations that would require further desemanticized grams to describe.
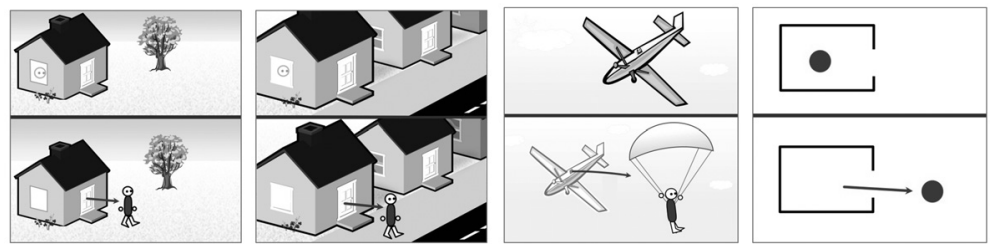

Figure 1. The four images from the questionnaire under observation (scaled down).

\subsection{Multidimensional scaling}

Multidimensional scaling is in essence a technique for measuring similarity and dissimilarity between the entities being analysed; when applied to linguistic phenomena, it produces a spatial representation of similarity between linguistic entities 
or functions (Croft and Poole 2008). The theory behind an MDS analysis is the same as that behind a semantic map analysis: the similarity relations and the semantic dimensions of the space are hypothesized to be part of a human speaker's conceptual organization (ibid.). All of the models displayed here are two-dimensional. More dimensions are technically possible, but would be considerably more difficult to read and, according to Croft (2010), lower-dimensional spatial models are superior since they constrain the analysis: the more dimensions added, the easier it is to make every point close to every other point with which it shares a linguistic form, there being a trade-off between minimizing spatial dimensions and maximizing goodness of fit.

The present study also takes as an example Levinson et al. (2003), who also used a set of pictures for elicitation, namely the Topological Relations Picture Series (TRPS; Bowerman and Pederson 1992), and multidimensional scaling to test the hypothesis that "the domain of topological relations constitutes a coherent semantic space with a number of strong attractors, that is, categories that languages will statistically tend to recognize even if some choose to ignore them" (Levinson et al 2003:502). For the current study, a new set of images was created, since the TRPS is for eliciting various static locative (and therefore adpositional) usages, such as IN, ON and UNDER, while this study concentrates on the lative usage of out exclusively. While the former study used the ALSCAL scaling algorithm (developed in 1977; see Cox and Cox 2001, esp. Chap. 11 for an overview of MDS methods), and were criticized for it by Croft and Poole (2008), the more recent PROXSCAL algorithm (which has the advantage of minimizing normalized stress ${ }^{1}$ ) is used in this study.

1 Stress reflects (inversely) the degree of correspondence between the MDS map display and the input matrix; the normalized stress value is independent of the scale and the number of dissimilarities. For this study, PROXSCAL scaling (version 1.0) in SPSS (version 20.0) was used. 


\section{Grouping and mapping}

\subsection{Grouping principles}

The usages of the spatial grams under observation among the speakers of the respective languages are quite varied, or gradient, especially in the Baltic languages. Figure 2 illustrates the

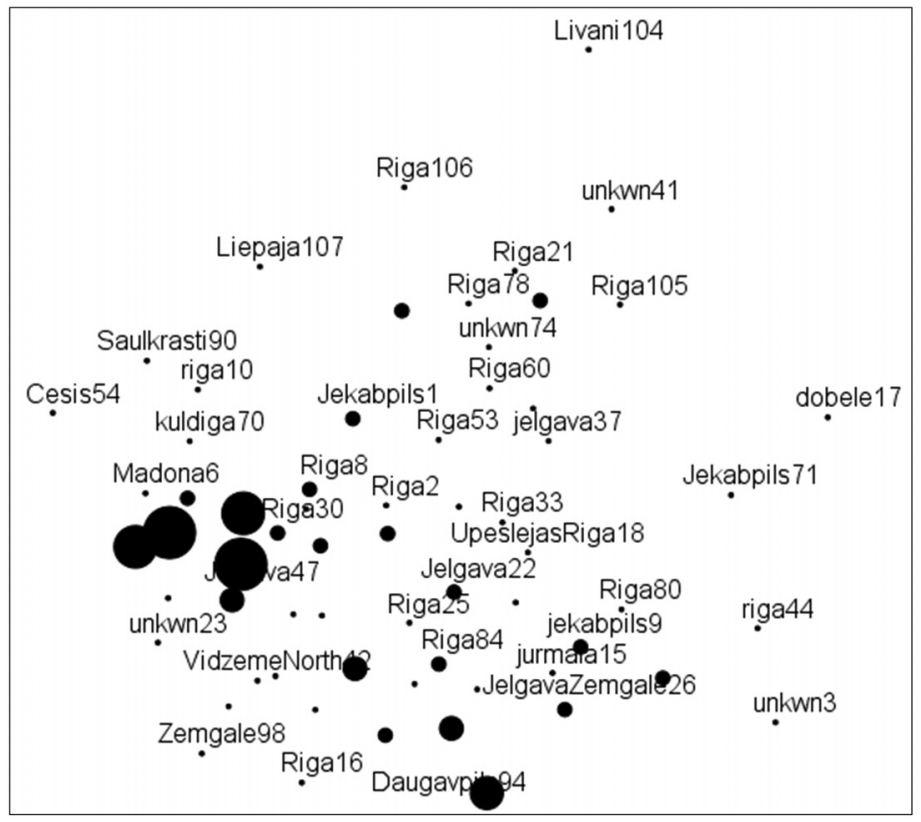

Figure 2. MDS map ${ }^{2}$ of the Latvian subjects (labelled by their self-reported place of origin), mapped according to their usage of the grams lauk $\bar{a}$ and $\bar{a} r \bar{a}$. Each marker stands for one or more subjects, and marker size reflects the number of overlapping data points: the biggest black dot stands for six subjects and the smallest dot for one subject. In the case of marker or label overlap, at most one subject label is shown (displaying all the 101 subject labels would render the map virtually incomprehensible).

2 PROXSCAL scaling algorithm, Euclidean distances, and ordinal proximity transformations; normalized raw stress $=0.05$; dispersion accounted for $=0.951$ 
diversity in the Latvian sample, with all four images considered and the usage of the grams lauk $\bar{a}$ and $\bar{a} r \bar{a}$ taken into account (but not $u z \bar{a} r u$; cf. Section 3.2). Relative proximity of the centres of the markers in Figure 2 is to be interpreted as the relative similarity in the usage of the spatial grams by the subjects. In other words, the closer any two subjects are on the map, the more similar is their language use; overlap of the markers indicates identical usage. For example, two subjects, Livani104 and Riga16, located furthest from each other, used the two grams almost completely differently: where one would rate a gram as 5 , the other would rate it as 0 .

The number of subjects and the variation between them is too large to map them all out in a single model to compare all individual usages, so the subjects were grouped (using clustering by Ward's method with squared Euclidean distances) based on the similarity of their answers to the four images. The Estonian data fits optimally into four, Võro into three and Latvian into seven groups (plus nine unique outliers that simply did not fit into any group). The goal was to minimize the number of groups, so minimal variation does occasionally occur within them; the mode value was used as a summarizing statistic to establish the collective group scores for each image. It should be noted that the groups do not seem to coincide with the traditional regional dialect divisions of the respective countries.

\subsection{Grams on a map}

Such variation in the usage of the grams is far from surprising. All of the spatial grams considered in this study have grammaticalized from lexical items, and apparently different speakers of the same language fall on somewhat different parts of the cline of the grammaticalizations, or as Andersen puts it, "differences in synchronic variation among members of a community may reflect the spread of an innovation through the community" (Andersen 2006: 66). This is illustrated in the MDS map (Figure 2) of the Estonian, Võro and Latvian data. 


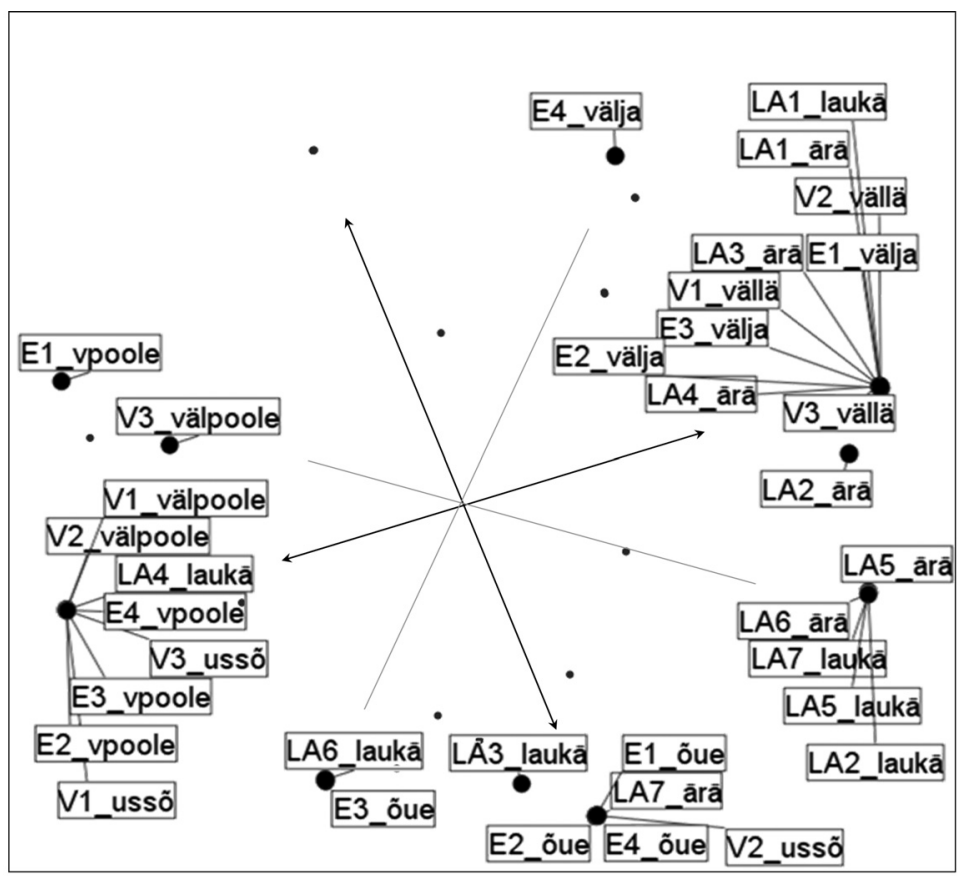

Figure 3. MDS map ${ }^{3}$ of the Estonian, Vorro and Latvian data. The Estonian väljapoole and Võro välläpoolõ have been abbreviated vpoole and välpoole respectively. The configuration does not correspond to real-world geographical locations (see below). See Appendix 1 for the (mode) scores for each gram by image (including outlier subjects) and Appendix 2 for the decomposition of the groups by subjects.

The map displays a conceptual space where each data point represents the usage of a given gram by one of the groups of one of the languages. The data point labels should be interpreted as follows: language [E(stonian), LA(tvian), V(õro)], subgroup within this language [1-7; cf. Section 3.1], [spatial gram]. The smaller dots without labels represent the ungrouped Latvian

3 PROXSCAL scaling algorithm, Euclidean distances and ordinal proximity transformations; normalized raw stress $=0.016$; dispersion accounted for $=0.984$. 
outliers (see Appendix 1). Again, the relative proximity of data points on the map reflects the similarity of the use of this spatial gram by the members of the given group in describing the four images; overlapping equals identical usage. Axes connecting diametrically opposed groups have been added - in the following, they will be used as in a compass with "N" marking "north". Note that this configuration has nothing to do with actual realworld geographical locations, and is used as a visual aid only. The clusters at the ends of the "compass" arrows represent the ends of the rating scales, with scores of either 5 (the maximum) or 0 (the minimum). All data points located somewhere in between the aforementioned represent cases where one or more of the mode scores is other than 5 or 0 . Two larger concentrations of data points can be observed: the cluster in the east is comprised of grams that were used to describe all four images (with maximal scores) - in contrast, clustered in the far west are grams that the subjects did not use at all to describe any of the images (all scores equalling zero), such as the fourth Latvian group lauk $\bar{a}-$ grammaticalized from "field", but apparently not grammaticalized far enough for all Latvian speakers, cf. the comment on the from-house-to-field image by subject Tukums62: "I would like to avoid "laukā" because it does not feel correct and it can be mixes up with "in field"." (spelling unchanged).

\subsection{Mapping (gradualness through) gradience}

The first step in the grammaticalization of something that is outdoors (the south-west point on the map) into the spatial gram 'outdoors' would have to involve extension and gradual desemanticization; the Estonian (third group) oue 'into the courtyard', 'to the outdoors' and Latvian (sixth group) lauka are examples of that. Decategorialization occurs as well, as the item loses morphosyntactic properties, such as declination capabilities (lexicalizing the stem and a case ending in this case into one non-analysable unit). Through further extension, the grammaticalizing item begins to signify the space outside one's door in 
general, as with õue for Estonians (except for the third group), or the Latvian seventh group $\bar{a} r \bar{a}$, in the southern point on the map. This is also the point where the gram ussõ stands for the Vorro second group, while the other Võro speakers did not use it as a spatial gram at all. In a case such as the Russian na ulicu 'into the street', 'to the outdoors', the images (to the field and to the street) would be swapped, of course. Grammaticalizing further, the gram finds usage in contexts different from exiting a building, for example exiting a plane into the void (south-east) or the movement of an abstract object out of another (east end). This is where most of the Estonian välja and the Võro cognate vällä are found, and most Latvians would use $\bar{a} r \bar{a}$ as such a general 'out' gram, while some (the first group) would use both $\bar{a} r \bar{a}$ and $l a u k \bar{a}$. From this point onward, functions in the left begin to disappear. The Estonian fourth group rated välja (initially grammaticalized from 'field') as unfit to describe the image depicting exiting a house into a field (two members in the group actually also found it unfit to describe exiting into the street). Two Latvian outliers (from Livāni and Saulkrasti) in the north end used laukā only to describe the plane image and the abstract one.

In the north-west, used only for the abstract image, is the Estonian (fourth group) väljapoole 'outwards', being the point where further decategorialization manifests itself: the gram has lost enough of its lexical substance to be combined with another gram, poole 'towards' (grammaticalized from 'side, half'), in which the meaning (and therefore the usage) focuses more on the 'towards' aspect or the PATH (instead of the GOAL of 'out'), being only suitable to describe an image which depicts the abstract opposition of the inside and outside. The väljapoole and the Võro välläpoolõ in the west end (not used at all) can be seen as instances where the gram can only be used to described the PATH and therefore not an image which focuses on the GOAL of the movement.

The Latvian $u z \bar{a} r u$ was excluded from the map, but if it were mapped, it would also lie in the north-west. It was given a score of 4 or 5 by only 11 subjects in the case of the abstract rectangle image (plus a few outlying scores for others) - but 
this group did not coincide with any of the other groups in the Latvian data, nor did the usage of the gram have any remarkable correlations with any other gram usage (with $\bar{a} r \bar{a}$, for the same image: Pearson's coefficient 0.26; sig 0.006). It can be concluded that the usage of this spatial gram depends on factors not covered in this study, possibly because it also puts the focus (at least for some of the subjects, judging from the comments) on the ongoing process or РATH of the movement, and perhaps some semantic constraints apply: "I would use "uz àru" only in a large

\begin{tabular}{|c|c|c|c|c|c|}
\hline 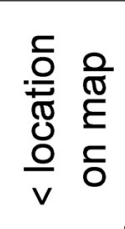 & $\frac{0}{0}$ & 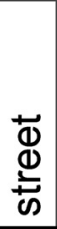 & $\frac{\stackrel{d}{c}}{\frac{\mathbb{d}}{2}}$ & $\begin{array}{l}\frac{0}{0} \\
\frac{\pi}{\pi} \\
\frac{\pi}{0} \\
\Phi\end{array}$ & $\begin{array}{l}<\text { image } \\
\text { examples } \\
\text { degree of grammaticalization }\end{array}$ \\
\hline W & & & & & LA4 laukā, V3 ussô \\
\hline SW & & & & & LA6 laukā, E3 õue \\
\hline$S$ & & & & & LA7 ārā, E1 õue \\
\hline SE & & & & & LA5 $\bar{a} r \bar{a}$, laukā \\
\hline $\mathrm{E}$ & & & & & E1-3 välja, LA1-4 ārā, V1-3 vällä \\
\hline NE & & & & & E4 vällä \\
\hline $\mathbf{N}$ & & & & & LA_Livani104 laukā \\
\hline NW & & & & & E1 väljapoole, (L uz āru) \\
\hline
\end{tabular}

Figure 4. A proposed diachronic dimension modelled through the gradience in the synchronic sample. The cardinal directions in the leftmost column correspond to the compass in Figure 3, used as a visual aid. The vertical axis represents a time-line, but it is not an absolute time-line charting the grammaticalization of this or that gram in time; rather, it is the proposed location of a gram in relation to its own grammaticalization process. 
building when saying that I am starting moving _towards_outside (only while in the building). I would tend to use "laukā" more often in a more rural place or a yard, less often in very urban places." (comment on the street image by subject Riga13; spelling unchanged). Figure 4 (which corresponds to Figure 3) summarizes the above, depicting the proposed cline of grammaticalization of the various lexical sources that have all yielded grams with various senses of 'out'.

Figure 4 also reflects what Haspelmath (2004: 33-34) has called rightward expansion in his model encompassing grammaticalization (rightward), retraction and antigrammaticalization (leftward) - as an item "forms a grammaticalization chain, some of its earlier manifestations on the left typically disappear, so that the chain loses on the left what it gains on the right."

\section{Concluding remarks}

Of the spatial grams discussed in this study, the World Lexicon of Grammaticalization (Heine and Kuteva 2004: 133) lists the Latvian lauk $\bar{a}$ as an example of the FIELD > OUT type of grammaticalization, and Svorou (1994: 258) lists the Lithuanian cognate laukan as an example of an environmental landmark $>$ EXTERIOR-REGION path. In the present study, an attempt has been made to take a look at the gradualness that underlies the " $>$ ", in between the usually reported ends of grammaticalization clines, in this case of the spatial grams of the EXTERIOR-REGION. Natural language change is gradual and proceeds in small steps, which can be observed as gradience in a synchronic sample of a language. For example, for some speakers of Latvian, laukā apparently does not function as a spatial gram for 'out' (it is likely that they analyse it rather as lauk- $\bar{a}$ field-LOCATIVE), and ussõ is used as 'to the outdoors' by some Võro speakers, but not all. What is also interesting to note is that the groups formed for comparative purposes in this study, based on the (dis)similarities of their questionnaire answers, mostly do not correspond to the areal dialects in the three languages. What conditions the spread and vi- 
ability of such innovations as grammaticalizing spatial grams in these languages would be an interesting topic for future investigation. An analysis of the data on all ten images of the questionnaire (see Section 2.1), with the addition of Lithuanian data, will be published in an upcoming Master's thesis by the author.

\section{Address:}

Andres Karjus

Ööbiku 14a

44315 Rakvere, Estonia

Tel.: +372 5532434

E-mail: andres.karjus@hotmail.com

\section{References}

Andersen, Henning (2006) "Synchrony, diachrony, and evolution". In Ole Nedergaard Thomsen, ed. Competing models of linguistic change: evolution and beyond, 59-90. (Current Issues in Linguistic Theory, 279.) Amsterdam: Benjamins.

Andrews, David R. (1999) Sociocultural perspectives on language change in diaspora: Soviet immigrants in the United States. Amsterdam and Philadelphia: John Benjamins Publishing Company.

Bowerman, Melissa and Eric Pederson (1992) "Topological relations picture series”. In Stephen C. Levinson, ed. Space stimuli kit 1.2: November 1992, 51. Nijmegen: Max Planck Institute for Psycholinguistics. Available online at http://fieldmanuals.mpi.nl/volumes/1992/bowped (accessed on 24.03.2012).

Cox, Trevor F. and Michael A.A. Cox (2001) Multidimensional scaling. 2nd ed. (Monographs on Statistics and Applied Probability, 88.) Florida: CRC Press LLC.

Croft, William and K. T. Poole (2008) "Inferring universals from grammatical variation: multidimensional scaling for typological analysis". Theoretical Linguistics 34, 1-37.

Croft, William (2010) "Relativity, linguistic variation and language universals". CogniTextes 4. Available at http://cognitextes.revues.org/303 (accessed on 24.03.2012)

de Rijk, Rudolf P.G. (2008) Standard Basque: a progressive grammar. Vol. 1. Cambridge. Mass.: Massachusetts Institute of Technology.

Fraenkel, Ernst (1962) Litauisches etymologisches wörterbuch. Band I. Heidelberg: Carl Winter; Göttingen: Vandenhoeck \& Ruprecht. 
Haspelmath, Martin (2004) "On directionality in language change with particular reference to grammaticalization”. In Olga Fischer, Muriel Norde, and Harry Perridon, eds. Up and down the cline - the nature of grammaticalization. Amsterdam and Philadelphia: John Benjamins.

Heine, Bernd and Tania Kuteva (2004) World lexicon of grammaticalization. Cambridge: Cambridge University Press.

Heine, Bernd and Tania Kuteva (2006) The changing languages of Europe. Oxford: Oxford University Press.

Hell, Karin and Harmut Katz (1982) "Zu selkupisch pō". Finno-Ugrische Mitteilungen 6, 175-177.

Hopper, Paul J. and Elizabeth Closs Traugott (2003) Grammaticalization. 2nd ed. Cambridge: Cambridge University Press.

Karulis, Konstantīns (2001) Latviešu etimologijas vārdnīca. Rīga: Avots.

KKVS = Torikka, Marja, ed. (2009) Karjalan kielen verkkosanakirja. (Kotimaisten kielten tutkimuskeskuksen verkkojulkaisuja, 18.) Available online at http://kaino.kotus.fi/kks (accessed on 24.03.2012).

Levinson Stephen, Sérgio Meira, and the Language and Cognition Group (2003) "NNatural concepts' in the spatial topological domain - adpositional meanings in crosslinguistic perspective: an exercise in semantic typology". Language 79, 3, 485-515.

Mažiulis Vytautas (1997) Prūsų kalbos etimologijos žodynas. Vol. 4. Vilnius: Mokslas, Mokslo ir enciklopedijų leidykla.

SKES = Itkonen, Erkki and Aulis J. Joki (1969). Suomen kielen etymologinen sanakirja. Helsinki: Suomalais-ugrilainen Seura.

Svorou, Soteria (1994) The grammar of space. Amsterdam and Philadelphia: John Benjamins.

Traugott, Elizabeth Closs and Graeme Trousdale (2010) "Gradience, gradualness and grammaticalization. How do they intersect?". In Elizabeth Closs Traugott, Graeme Trousdale, eds. Gradience, gradualness and grammaticalization 45-73. Amsterdam: John Benjamins.

VES = Sullõv, Jüvä (2001) Võro-eesti synaraamat. Võro: Võro Instituut. Available online at http://www.folklore.ee/ Synaraamat (accessed on 24.03.2012)

VKS = Vadja keele sõnaraamat 1-7. Tallinn: Eesti Keele Sihtasutus, 1990-2011.

Kokkuvõte. Andres Karjus: Läänemere kallastel väljas: gradientsus välisruumi grammatisatsioonis. Leksikaalse keeleüksuse muutumine grammatilisteks loomulikus keeles hõlmab endas tingimata vahepealseid astmeid. Selle uurimuse kaks keskset mõistet on diakrooniline graduaalsus ja sünkrooniline gradientsus, teisisõnu, et loomulikud keelemuutused ei toimu üleöö, ja et muutused liiguvad edasi üksikute keelekogukonna liikmete kaudu (vt Traugott ja Trousdale 2010: 23, 26). Uurimuses püüan modelleerida graduaalsust gradient- 
suse kaudu, kasutades selleks andmestikku, mis pärineb küsitlusest välisruumigrammide (vt Svorou 1994) kohta eesti, võru ja läti keeles. Analüüsiks ja selle tulemuste visualiseerimiseks kasutan multidimensionaalset skaleerimist, statistilist meetodit, mis sarnaneb kasutuse poolest semantilisele kaardistamisele.

Märksõnad: grammatisatsioon, graduaalsus, gradientsus, ruumisõnavara, multidimensionaalne skaleerimine, Läänemere ümbruse keeled

Appendix 1. Group Mode Scores (Including the Latvian Outliers)

\begin{tabular}{|c|c|c|c|c|c|c|c|c|c|}
\hline $\begin{array}{l}\text { language } \\
\text { group_gram }\end{array}$ & & $\begin{array}{l}\text { ield } \\
\text { Pla } \\
\mid\end{array}$ & ane & $\begin{array}{l}\text { e } \\
\text { cta } \\
\text { st }\end{array}$ & $\begin{array}{l}\text { angle } \\
\text { reet }\end{array}$ & & & & \\
\hline E1_välja & 5 & $5: 5$ & $5: 5$ & 5 & LA_Jelgava26_laukā & 5 & 0 & & 1 \\
\hline E2_välja & 5 & 55 & $5:$ & 5 & LA_Cesis54_ārā & 5 & 5 & 5 & 0 \\
\hline E3_välja & 5 & $5: 5$ & $5:$ & 5 & LA_Cesis54_laukā & 5 & 5 & 5 & 0 \\
\hline E1_õue & 5 & \begin{tabular}{l|l}
0 & 0 \\
\end{tabular} & 0 & 5 & LA_Riga105_laukā & 4 & 4 & 0 & 4 \\
\hline E2_õue & 5 & $\begin{array}{lll}0 & 0 \\
\end{array}$ & 0 & 5 & LA_Jekabpils71_ārā & 4 & 0 & 0 & 4 \\
\hline E4_õue & 5 & $0 \quad 0$ & $0:$ & 5 & LA_Riga80_laukā & 4 & 0 & 0 & 3 \\
\hline E3_õue & 5 & $0 \quad 0$ & 0 & 0 & LA_Jelgava26_ārā & 3 & 4 & 4 & 0 \\
\hline E4_välja & 0 & 55 & $5:$ & 5 & LA_Riga69_ārā & 0 & 5 & 0 & 5 \\
\hline E1_vpoole & 0 & 05 & 5 & 0 & LA_Riga80_ārā & 0 & 5 & 0 & 5 \\
\hline E2_vpoole & 0 & \begin{tabular}{|l|l}
0 & 0 \\
\end{tabular} & 0 & 0 & LA_dobele17_laukāā & 0 & 0 & 1 & 3 \\
\hline E3_vpoole & 0 & 00 & 0 & 0 & LA_Livani104_laukā & 0 & 5 & 5 & 0 \\
\hline E4_vpoole & 0 & \begin{tabular}{|l|l}
0 & 0 \\
\end{tabular} & 0 & 0 & LA_Saulkrasti90_laukā & 0 & 5 & 5 & 0 \\
\hline LA1_ārā & 5 & $5 \mid 5$ & $5:$ & 5 & LA_unkwn3_ārā & 0 & 5 & 5 & 0 \\
\hline LA1_laukā & 5 & 55 & $5:$ & 5 & LA_uzāru & 0 & 0 & 5 & 0 \\
\hline LA3_ārā & 5 & $5: 5$ & $5:$ & 5 & LA_Riga105_ārā & 0 & 0 & 4 & 0 \\
\hline LA4_ārā & 5 & 55 & 5 & 5 & LA_dobele17_ārā & 0 & 0 & 0 & 0 \\
\hline LA2_ārā & 5 & \begin{tabular}{|l|l}
5 & 4 \\
\end{tabular} & $4:$ & 5 & LA_Jekabpils71_laukā & 0 & 0 & 0 & 0 \\
\hline LA2_laukā & 5 & 50 & 0 & 5 & LA_Livani104_ārā & 0 & 0 & 0 & 0 \\
\hline LA5_ārā & 5 & \begin{tabular}{|l|l}
5 & 0 \\
\end{tabular} & $0:$ & 5 & LA_unkwn3_laukāa & 0 & 0 & 0 & 0 \\
\hline LA5_laukā & 5 & $5 \mid c$ & 0 & 5 & V1_vällä & 5 & 5 & & 5 \\
\hline
\end{tabular}




\begin{tabular}{|c|c|c|c|c|c|c|c|}
\hline LA6_ārā & \begin{tabular}{l|l}
5 & 5 \\
\end{tabular} & \begin{tabular}{|l|l|}
5 & 0 \\
\end{tabular} & 5 & V2_vällä & 5 & 55 & $5 \mid 5$ \\
\hline LA7_laukāa & \begin{tabular}{l|l}
5 & 5 \\
\end{tabular} & \begin{tabular}{|l|l|}
5 & 0 \\
\end{tabular} & 5 & V3_vällä & 5 & 55 & 55 \\
\hline LA7_ārā & \begin{tabular}{|l|l}
5 & 0 \\
\end{tabular} & \begin{tabular}{l|l}
0 & 0 \\
\end{tabular} & 5 & V2_ussõ & 5 & 00 & 05 \\
\hline LA3_laukā & \begin{tabular}{|l|l}
5 & 0 \\
\end{tabular} & \begin{tabular}{l|l}
0 & 0 \\
\end{tabular} & 4 & V3_välpoole & 1 & $0{ }^{0}$ & 40 \\
\hline LA6_laukā & \begin{tabular}{l|l}
5 & 0 \\
\end{tabular} & \begin{tabular}{l|l}
0 & 0 \\
\end{tabular} & 0 & V1_ussõ & 0 & 0 & $0 \mid 0$ \\
\hline LA4_laukā & \begin{tabular}{l|l}
0 & 0 \\
\end{tabular} & \begin{tabular}{l|l|}
0 & 0 \\
\end{tabular} & 0 & V1_välpoole & 0 & $0 \quad($ & 00 \\
\hline LA_Saulkrasti90_ārā & 55 & \begin{tabular}{|l|l|}
5 & 5 \\
\end{tabular} & 5 & V2_välpoole & 0 & $0 \quad($ & 00 \\
\hline LA_Riga69_laukā & \begin{tabular}{l|l}
5 & 0 \\
\end{tabular} & \begin{tabular}{l|l|l|}
0 & 3 \\
\end{tabular} & 4 & V3_ussõ & 0 & \begin{tabular}{l|l}
0 & 0 \\
\end{tabular} & 0 \\
\hline
\end{tabular}

\section{Appendix 2. Subject Groupings}

LA1: Daugavpils32, Dobele93, Jekabpils4, Jelgava47, Jurmala89, kuldiga70, Kurzeme92, Kurzeme96, Madona6, PriekuleLiepajas99, Rezekne87, Riga, 19, riga10, Riga34, Riga38, Riga39, Riga55, Riga59, Riga68, Riga76, Riga81, Riga88, Sigulda83, unkwn14, unkwn23, unkwn49, Valmiera63, Vidzeme45, VilakaLatgale27

LA2: Kurzeme108, Riga, 91, Riga11, Riga13, Riga30, Riga48, Riga56, Talsi97, Ventspils51

LA3: Balvi36, Daugavpils40, jelgava73, Kurzeme86, Riga102, Riga25, Riga65, Riga67, Riga8, Riga85, Valmiera43, VidzemeNorth42

LA4: Jekabpils82, Jelgava29, Jurmala50, Latgale61, Livani7, Riga16, Riga52, Riga77, Salaspils28, unkwn66, Vidzeme20

LA5: Daugavpils94, Jekabpils1, Jelgava22, jelgava37, Riga2, Riga75, Riga79, Riga84, Zemgale98, unkwn12, Ventspils109

LA6: Aizkraukle100, jekabpils9, Jelgava101, jurmala15, riga44, Riga95, UpeslejasRiga18

LA7: Jekabpils46, Liepaja107, Riga, 21, Riga103, Riga106, Riga33, Riga53, riga57, Riga58, Riga60, Riga78, unkwn41, unkwn74

E1: Harjumaa31, Keila30, Tartu33, Tartu8, Hiiumaa17, LVirumaa1, Rakvere11, rakvere29, Rakvere39, Tallinn3, Tartu22, Tartu28, Tartu40, Tartu42, Tartu7, Tartumaa16, tartumaa23, Tartumaa9, Türi27, Võrumk32

E2: Tallinn2, Tallinn6, Tartu14, Tartu26, Tartust25, unkwn15

E3: Rakvere20, Tartumaa38, unkwn4, Harjumaa34, Tartu41, Võru36, Tartu12, unkwn21, Viljandimaa+kagu5, Võru37

E4: LVirumaa10, LVirumaa19, tartu18, Tartu24, Tartumaa35, unkwn13

V1: Lasva-Vastseliina.Rõugõ19, Mõniste10, Põlvamaa18, Põlvamaa22, unkwn13, VanaVõrumaa5, Võru24, Võrumaa.Kose14, Väimela20

V2: Mõniste1, Urvastõ2, Võru8, Võrumaa23, Rõuge7, Võru9

V3: Navi/Puspuril6, Navi17, Põlvamaa16, Põlvamaa3, Valgamaa12, Võru26, Võru4, Võrumaa.Kääpa25, Võrumaa.Paganamaa11, Võrumaa15, Võrumaa21 
